\title{
ЗОВНІШНЯ ПОЛІТИКА РУМУНІЇ ЗА ПРЕЗИДЕНТІВ Т. БЕСЕСКУ ТА К. ЙОХАННІСА: ПОРІВНЯЛЬНИЙ АНАЛІЗ
}

Анотація. Дана стаття присвячена аналізу зовнішньополітичної ділльності Румунії за президентів Т. Бесеску і К. Йоханніса, які доклали максимальних зусиль аби вивести країну на новий рівень розвитку та зарекомендувати ї̈ серед провідних акторів міжнародної арени як стабільну країну, яка готова до співпращі на регіональному та глобальному рівнях. Розглянувши ключові вектори зовнішньої політики Румунії за президентства иих двох абсолютно різних постатей, можемо сказати, що в основному вони були подібними, хоча й мали свої особливості.

Ключові слова: зовнішня політика, Румунія, Т. Бесеску, К. Йоханніс, ЄС, США, РФ

Пройшовши складний шлях становлення нової незалежної держави, сьогодні Румунія постає перед нами у зовсім іншому міжнародно-політичному контексті, на відміну від XX ст. Нині це інвестиційно-приваблива країна, яка має розширенні зовнішні торгово-економічні відносини з країнами ЄС та США. Країна, яка враховуючи сучасні глобальні події, регіональні питання, безпекову нестабільність у Східній Європі, й надалі продовжує активізувати свою зовнішньополітичну діяльність, реалізуючи її ключові вектори. 3 огляду на це, наразі існує нагальна потреба у поглибленому дослідженні зовнішньої політики екс-президента Румунії Траяна Бесеску та нинішнього президента Клауса Йоханніса.

На сьогодні дана тематика викликає зацікавлення як серед вітчизняних, так і закордонних дослідників, які у своїх наукових працях намагаються розкрити різні вектори зовнішньої політики Румунії з 2004 р. по сьогодення. Зокрема, вивчення пріоритетів політики колишнього керманича Румунії та його конкурентів має місце у працях румунського спеціаліста М. Борзого ${ }^{1}$, бухарестського журналіста О. Нахояㄹ, румунського політич-

\footnotetext{
• Вовчук Людмила Анатоліївна - кандидат історичних наук, доцент кафедри міжнародних відносин та зовнішньої політики Чорноморського національного університету імені Петра Могили (м. Миколаїв); ORCID: https://orcid.org/0000-0002-8324-5235; e-mail: luda_vovchuk@ukr.net

${ }^{1}$ Barzoi M. Politic Show: Anul politic 2014. Cati parlamentari au profitat de imunitate; Fundatia si partidul Miscarea Populara se intrec in invitatii pentru Basescu; Prioritatile pe agenda externa a lui Iohannis: Moldova si Germania // HotNews.ro: офіщійна сторінка. 2014. 30 December. URL: http://revistapresei.hotnews.ro/stirirevista_presei_politic-18963799-politic-show-anul-politic-2014-cati-parlamentari-profitat-imunitate-fundatiapartidul-miscarea-populara-intrec-invitatii-pentru-basescu-prioritatile-agenda-externa-lui-iohannis-moldovagermania.htm

${ }^{2}$ Nahoi O. Romania: Balancing two hatreds // EurActiv: офіційна сторінка. 2012. 9 July. URL: http://www.euractiv.com/elections/romania-balancing-hatreds-analysis-513802
} 
ного кореспондента О. Станку 33 та румунського дослідника А. Тудора ${ }^{4}$.

Різного роду аспекти двосторонньої співпраці Румунії та Молдови грунтовно висвітлюють молдавські дослідники. Серед яких на особливу увагу заслуговують праці А. Дев'яткова ${ }^{5}$, Д. Чубашенка ${ }^{6}$, Т. Сорочану ${ }^{7}, \quad$ К. Міхалаке ${ }^{8}, \quad$ С. Назарія ${ }^{9}$, Б. Цирді ${ }^{10}$ та К. Ільїної ${ }^{11}$.

Аналізуючи стан вітчизняної науки щодо даної тематики, варто відзначити, що українські дослідники переважно приділяють значну увагу висвітленню проблем і перспектив вступу Румунії до ЄС та НАТО, і стану їх відносин після вступу до цих організацій: Т. Рендюк ${ }^{12}$, Л. Мельничук ${ }^{13}$, А. Скляр ${ }^{14}$, А. Поляшенко і Л. Вовчук ${ }^{15}$. Окрім того, значну

\footnotetext{
${ }^{3}$ Stancu 0. Basescu insista: Apel inainte de decizia Tribunalului // Jurnalul Naţional: офіційна сторінка. 2005. 25 November. URL: http://jurnalul.ro/special-jurnalul/basescu-insista-apel-inainte-de-decizia-tribunalului33955.html

${ }^{4}$ Tudor A. Iohannis minte! El este candidatul impus de Băsescu // Jurnalul Naţional: офіційна сторінка. 2014. 13 August. URL: http://jurnalul.ro/stiri/observator/iohannis-minte-sau-este-grav-amnezic-de-ce-dupa-amiazaamericanilor-este-seara-la-iohannis-675311.html

${ }^{5}$ Девяткков А.В. Контуры румынской политики в отношении Республики Молдова // ПЕРСПЕКТИВЫ: офіщійна сторінка. $2012 . \quad 8$ июля. URL:
}

http://www.perspektivy.info/history/kontury_rumynskoj_politiki_v_otnoshenii_respubliki_moldova_2012-07-

08.htm

${ }^{6}$ Чубашенко Д. Унионизм - доктрина умственно отсталых // AVA.MD: информационно-аналитический портал [офіційна сторінка]. 2012. 30 марта. URL: http://ava.md/analytics-commentary/015249-unionizm--doktrina-umstvenno-otstalih.html

${ }^{7}$ Сорочану T. Траян Бэсеску и «Новые правые» // Независимая Молдова: офіщійна сторінка. 2009. 20 мая. URL: http://www.nm.md/article/trayan-besesku-i-novye-pravye

${ }^{8}$ Михалаке К. Вставай, Молдова! // Независимая Молдова: офіційна сторінка. 2013. 10 декабря. URL: http://www.nm.md/article/vstavay-moldova

${ }^{9}$ Назария C. Траян «Младший» продолжает удивлять европейскую общественность // AVA.MD: информационно-аналитический портал [офіщійна сторінка]. 2008. 23 апреля. URL: http://ava.md/01-politika/0609trayan-mladshii-prodolzhaet--udivlyat--evropeiskuq-obshestvennost.html

${ }^{10}$ Цырдя Б. На этот раз Бэсеску был сдержаннее // Комсомольская Правда Молдовы: офіційна сторінка. 2013. 18 июля. URL: http://www.kp.md/online/news/1489818/

${ }^{11}$ Ильина K. Сценарий аншлюса // Новости Молдовы [офіційна сторінка]. 2013. 4 марта. URL:http://www.noi.md/ru/news_id/19444

${ }^{12}$ Євроатлантичний вектор зовнішньої політики Румунії // Політичні та соціологічні студії. Т. IX. Тематичний випуск. Політичний регіоналізм і політична регіоналістика: емпіричні та теоретичні аспекти. Чернівці: «Букрек». 2010. С. 305-318.

${ }^{13}$ Мельничук Л.Н. Путь Румынии в Европейский союз: опыт для Украины // Журнал «Вісник Національного університету «Юридична академія України імені Ярослава Мудрого». Серія: Філососфія, філософія права, політологія, соціологія. 2012. № 4 (14). С. 2-12.

${ }^{14}$ Скляр А. Румунія не ПРОти // Зовнішні справи. 2011. № 7/8. С. 33-37.

${ }^{15}$ Вовчук Л.А., Полященко А.С. Стан відносин між Румунією та Європейським Союзом після вступу до організації // Емінак: науковий щоквартальник. 2018. №1 (21) (січень-березень). Т. 2. С. 83-87; Поляшенко А.С. Вступ Румунії до Європейського Союзу // Конституція - основа розвитку національного законодавства: Матеріали Х Всеукраїнської студентської науково-практичної конференції. 28 квітня 2015 р. Миколаїв: НУК, 2015. С. 8688; Поляшенко А.С. Відносини між Україною та Румунією за президентства Клауса Йоханніса (2014-2017рp.) // Південна Україна у міжнародних відносинах: історія та сучасність. Збірник матеріалів Х Всеукраїнської науково-практичної конференції студентів і молодих вчених (9 червня 2017 р.). За ред. О.П. Тригуба. Миколаїв, 2017. С. 52-55. 
цінність становлять роботи української дослідниці А. Гавюк ${ }^{16}$, С. Лазоренка ${ }^{17}$, які вивчають сучасну зовнішню політику Румунії з урахуванням досягнень попередника К. Йоханніса Т. Бесеску.

Не менш важливими є й роботи російських дослідників, які пишуть про аспекти реваншизму та європейського націоналізму у зовнішній політиці Т. Бесеску (В. Сорокін ${ }^{18}$, Т. Биткова ${ }^{19}$, Ю. Ревін ${ }^{20}$ ), про непрості та суперечливі відносини між Румунією і РФ $\left(\right.$ В. Кирилов ${ }^{21}$, В. Трухачов ${ }^{22}$ ), пріоритетність у зовнішньополітичній діяльності Румунії (А. Везуїна ${ }^{23}$.

Однак, не дивлячись на наявну кількість наукових праць, дана тематика потребує більш поглибленого дослідження.

Аби зрозуміти особливості зовнішньополітичної діяльності Румунії упродовж останніх 16 років, потрібно здійснити порівняльний аналіз зовнішньої політики країни за президентів Т. Бесеску та К. Йоханніса, звернувши увагу на: а) європейський напрямок і відносини з країнами-сусідами у зовнішній політиці двох президентів Румунії, визначивши найважливіші результати, яких досягла Румунія після вступу до ЄC; б) ставлення керівників держави до перспектив співпраці з РФ; в) позиції Т. Бесеску і К. Йоханніса щодо відносин Румунії з НАТО.

Т. Бесеску є однією з найяскравіших і найпомітніших політичних постатей Європи, який відомий своїми екстравагантними витівками та висловлюваннями, які інколи вражають і шокують європейців надмірною агресивністю та потенційною небезпекою. Проте, якщо розглядати його реальні дії у зовнішній політиці у більш широкому європейському контексті, то вони представляють собою концентроване вираження тенденцій, які можна спостерігати у низці держав, що стали членами ЄС у 2000-х рр., це, наприклад, активне позиціонування себе на міжнародній арені, налагодження тісного економічного і політичного партнерства з іншими державами та прагнення відігравати у світовій полі-

\footnotetext{
${ }^{16}$ Гавюк А. Чорноморський вектор зовнішньої політики Румунії: автореф. дис.... канд. політ. наук: 23.00.04; Чернів. нац. ун-т ім. Юрія Федьковича. Чернівці, 2015. 20 с.; Гавюк А. Діяльність Румунії в рамках Організації Чорноморського Економічного Співробітництва // Матеріали VIII Міжнародної науково-практичної конференції студентів та молодих вчених «Актуальні проблеми зовнішньої політики України». м. Чернівці, 2014. C. 21-23.

${ }^{17}$ Лазоренко С. Значення та зростаюча роль Румунії у́ Чорноморському регіоні // Матеріали VIII Міжнародної науково-практичної конференції студентів та молодих вчених «Актуальні проблеми зовнішньої політики України». м. Чернівці, 2014. С. 59-61.

${ }^{18}$ Сорокин B. Кто и почему не признал Косово? // Военновости.ру: офіційна сторінка. 2011. 15 сентября. URL: http://voennovosti.ru/2011/09/kto-i-pochemu-ne-priznal-kosovo/

${ }^{19}$ Биткова Т.Г. Румыния в единой Европе // Актуальные проблемы Европы. 2007. № 4. С. 129-141.

${ }^{20}$ Ревин Ю. Бэсеску: румынский блеф // APN.MD: новинний портал [офіщійна сторінка]. 2014. 10 февраля. URL: http://apn.md/ru/persona-nedeli/1050-besesku-rumynskij-blef

${ }^{21}$ Кириллов В.Б. Отношения России и Румынии после 1989 года в контексте внешнеполитических приоритетов страны // ВЕСТНИК МГИМО-УНИВЕРСИТЕТА. 2012. № 2. С. 13-23.

${ }^{22}$ Трухачёв В. Бухарест задирает Москву // СТОЛЕТИЕ: информационно-аналитическое издание [офіщійна сторінка]. 2014. 5 ноября. URL: http://www.stoletie.ru/zarubejie/buharest_zadirajet_moskvu_461.htm

${ }_{23}^{23}$ Везуина М.-А. Внешняя политика Румынии в видении Клауса Йоханниса. «Синергическая политика: национальная, европейская и евро-атлантическая» // Молодой ученый. 2015. №19. С. 531-535; Везуина M.-А. Внешняя политика Румынии в Черноморском регионе // Гуманитарные, социально-экономические и общественные науки. № 11. Т. 1. 2015. С. 93-94.
} 
тиці більш вагому роль ${ }^{24}$. Після приходу до влади Т. Бесеску Румунія була в числі перших соціалістичних країн, які висловили своє бажання приєднатися до спільноти європейських держав. Однак, новообраному президенту довелося вирішувати безліч проблем, які перешкоджали євроінтеграції країни, а саме: зміцнення демократії, дотримання прав людини, підвищення ефективності роботи адміністративного апарату, введення стандартів європейського законодавства, поліпшення становища національних меншин ${ }^{25}$. Президент Румунії неодноразово наголошував, що приналежність держави до Європейського Союзу $€$ головним пріоритетом зовнішньої політики Бухареста ${ }^{26}$.

Вступ до ЄС у 2007 р. став головним досягненням Румунії в її новітній історії. Країна отримала можливість повернутися до Європи та налагодити життя народу на основі справжніх європейських цінностей і принципів, завести іноземні інвестиції у розвиток румунської економіки, реформувати систему державного управління, довівши її до європейського стандарту.

Окрім цього, це дало можливість Румунії налагодити відносини з провідними країнами ЄC і проводити активну регіональну політику, яка характеризувалася відвертим натоцентризмом і підпорядкованістю пріоритетним завданням якнайшвидшої подальшої інтеграції до західних економічних і військово-політичних структур.

Слід наголосити на тому, що у цей час Т. Бесеску приділяв велику увагу тісним взаєминам з Францією та Німеччиною. У липні 2008 р. Франція почала масштабну кампанію по депортації зі своєї держави циганських нелегалів. По всій території було ліквідовано близько 100 наметових містечок, вислано біля 1000 циган ${ }^{27}$. Ці заходи були зустрінуті різкою критикою державами-членами ЄС. Румунія, яка має найбільше циганське населення серед країн ЄС, була однією з перших країн, хто почав обговорення цього проблемного питання 3 Н. Саркозі ${ }^{28}$. Був проведений двосторонній діалог між державами і в ході цих переговорів сторони домовилися про спільне вирішення «циганського питання».

Що стосується відносин з Німеччиною, то, загалом, А. Меркель надавала дуже потужну підтримку як самому Т. Бесеску, так і його зовнішньополітичному курсу, оскільки Румунія була і є для Німеччини важливим стратегічним партнером. Але в останній рік свого президентського терміну Т. Бесеску свідомо пішов у протистояння з Берліном. Причиною цьому стали уніоністські політичні прагнення Бесеску, метою яких було поглинання Молдови Румунською державою. Тобто, реалізація Бессеску його офіційно неоголошеної доктрини, що грунтувалася на принципах панрумунізму, згідно з якою Республіка Молдова може стати або складовою частиною румунської держави, або ж зберегти молдавську державність, за умови стати повноправною країною-членом ЄС поруч з Румунією. Канцлер Німеччини виступила 3 публічним засудженням цих прагнень. Досить цікавим є те, що у ситуації з визнанням Республіки Косово, Т. Бесеску, слідуючи, насамперед,

\footnotetext{
${ }^{24}$ Интеграция по-румынски. URL: http://moldnews.md/rus/news/23324

${ }^{25}$ Корнилов А.А. Взаимоотношения Румынии и ЕС до открытия переговоров о присоединении. С. 245.

${ }^{26}$ Корина K. Президент Траян Бэсеску выступил перед Парламентом. URL: http://www.rri.ro/ru_ru/10_16_марта_2013_г-2043

${ }^{27}$ Кузьменко C. Президент Румынии попросит Саркози не выселять цыган. URL: http://news.tochka.net/52310prezident-rumynii-poprosit-sarkozi-ne-vyselyat-tsygan/

${ }^{28}$ Президент Румынии просит Саркози решить вопрос с цыганами. URL: http://news.21.by/world/2010/09/23/160376.html
} 
національним інтересам держави, не визнав Косово самостійним державним утворенням. Однак, незважаючи на велику кількість протиріч у відносинах Румунії та Молдови, Т. Бесеску неодноразово підтримував країну-сусіда у прагненні приєднатися до ЄС.

Ставши членом «Європейської родини», серйозною проблемою у відносинах між ЄC і Румунією стало неприйняття останньої до Шенгенської зони з причини високого рівня корупції й організованої злочинності. А, як відомо, подолання саме цих проблем є першим критерієм на «входження до зони Шенгену». Розуміючи складність і довготривалість подолання цієї перепони, у 2011 р. Т. Бесеску, виступаючи по національному телебаченню, звинуватив канцлера ФРН А. Меркель і президента Франції Н. Саркозі у нав'язуванні своєї волі іншим членам ЄС у питанні недопущення Румунії до Шенгенської зони.

Виходячи з цього, можемо говорити, що маневр Т. Бесеску до ведення зовнішньої політики суперечив базовим принципам європейської інтеграції, оскільки за час його правління Бухарест дуже часто з'ясовував відносини зі своїми сусідами щодо історичної приналежності тієї чи іншої території. Подібні заяви президента Румунії стимулювали відповідні настрої у країні, а також його політика ставила під сумнів стабільність Південно-Східної частини Європи. Т. Бесеску часто використовував націоналістські та реваншистські гасла і заклики. Такий підхід не відповідав європейським стандартам у веденні зовнішньої політики.

К. Йоханніс, який прийшов до влади у жовтні 2014 р., у своїй президентській програмі «Румунія - країна добре виконаної роботи» зобов'язався поважати державну програму й, отже, продовжити основні напрямки зовнішньої політики та безпеки останніх років $^{29}$.

Головними проблемами безпеки і зовнішньої політики Румунії за президентства К. Йоханніса були: економічна переорієнтація Росії на азіатський континент, а також приєднання Румунії до Шенгенської зони та нестабільна ситуація у Східній Европі.

На початку своєї президентської діяльності новий президент Румунії К. Йоханніс заявив, що буде працювати над європейським розвитком Румунії і задасть курс до більш ефективної та прискореної інтеграції країни до ЄС. Якщо говорити про основні зовнішньополітичні здобутки К. Йоханніса у сфері співробітництва Румунії з ЄС, то слід виділити такі моменти:

1) Румунія прагматично зміцнила партнерські відносини і розвивала співробітництво $з$ державами-сусідами ЄС, докладала істотних зусиль щодо оновлення Європейської політики сусідства, а також посилення Східного партнерства.

2) Румунія консолідувала стратегічне партнерство та привілейовані відносини 3 Німеччиною, Францією, Польщею, Італією, Іспанією, Великобританією. Адміністрація К. Йоханніса розглядала Німеччину як ключового стратегічного партнера в ЄС. У двосторонніх відносинах з країнами Заходу найбільш тісні зв'язки у Румунії встановилися з Італією та Францією. У результаті, інвестиції цих країн у розвиток румунської економіки

\footnotetext{
${ }^{29}$ ACL's Klaus Iohannis presents his programme «Romania of Things Well Done». URL: http://www.agerpres.ro/english/2014/09/29/acl-s-klaus-iohannis-presents-its-programme-romania-of-thingswell-done--13-08-11; The Focal Point A «Romania of things well done». URL: http://bne-staticproduction.s3.amazonaws.com/dispatch-pdf/2014-11-27/0f5e-Romania\%20well\%20done\%20The_Focal_Point251114(1).pdf
} 
були найбільшими. Окрім того, посилилася двостороння співпраця Румунії та Великобританії у рамках ЄC і НАТО, а також у питаннях національної безпеки та боротьби 3 транскордонною злочинністю.

3) Зміцнення двосторонніх відносин Румунії з країнами-сусідами. Так, румунськоболгарські відносини, які періодично відчувають на собі вплив «історичних» суперечок 3 приводу приналежності тих чи інших територій, сьогодні $є$ прикладом толерантності та партнерства. За останні 10 років товарообіг Болгарії та Румунії збільшився у 8 разів.

Українсько-румунські дипломатичні відносини, які, фактично 3 проголошенням незалежності України, відрізнялися своєю нестабільністю (проблема делімітації морських кордонів виняткової економічної зони та континентального шельфу Чорного моря у районі острова Зміїний, а також претензіями через судноплавний канал Дунай-Чорне море), з 2014 р. характеризуються зростання підтримки євроінтеграційних прагнень України зі сторони Румунії.

В умовах війни на сході України питання безпеки стає особливо важливим напрямком взаємодії між двома державами. Вже у березні 2014 року Румунія засудила агресію РФ в Україні та закликала світове співтовариство до адекватної реакції на нові виклики та загрози. Новообраний президент підтвердив готовність Бухареста підтримати санкції $Є \mathrm{C}$ проти $Р \Phi^{30}$. Упродовж 2015-2016 pр. спостерігаються великі зрушення у налагодженні ефективної співпраці між двома країнам. Однак, прийнятий у 2017 р. в Україні Закон «Про освіту» призвів до відкритого виступу К. Йоханніса щодо цього закону, який на його думку «практично ...жорстко обмежує права національних меншин навчатися рідною мовою» ${ }^{31}$.

Поглиблення діалогу притаманне й у відносинах з Угорщиною, яка підтримує Румунію у питанні міграції, в тому сенсі, що зовнішні кордони ЄС повинні бути захищені.

4) Протягом перебування при владі адміністрації К. Йоханніса Румунія виступає за розширення $\mathrm{C} \mathrm{і} \mathrm{НАТО.} \mathrm{Так,} \mathrm{надається} \mathrm{серйозна} \mathrm{підтримка} \mathrm{вступу} \mathrm{Республіки} \mathrm{Молдова}$ до Європейського Союзу. А також Румунія виступає за приєднання Чорногорії до НАТО, яке, на думку К. Йоханніса, принесе багато користі цій країні та стане новим етапом в історії Чорногорії.

5) Як і його попередник, К. Йоханніс займає принципову позицію щодо невизнання незалежності Республіки Косово від Сербії. Президент Румунії заявив, що бажає бачити всі Балканські народи разом, як дружніх сусідів, і готовий надати підтримку Сербії у процесі вступу держави до ЄС.

6) Якщо чотирнадцять років тому Румунія стала членом НАТО і перебувала у процесі приєднання до ЄС (за президентства Т. Бесеску), то у 2018 р. завдання на міжнародному рівні радикально відрізнялися, враховуючи, що румунська держава: мала новий статус у межах НАТО; стала частиною ЄС; встановила стратегічне партнерство із $\mathrm{CWA}^{32}$. За

\footnotetext{
${ }^{30}$ Нечаєва-Юрійчук Н. Українсько-румунські відносини на сучасному етапі: виклики Євромайдану // Editura Muzeului Satmarean. 2016. № 1 (190). P. 395.

${ }^{31}$ National Minorities Oppose Ukraine's New Education Law. URL: https://en.hromadske.ua/posts/nationalminorities-oppose-ukraines-new-education-law

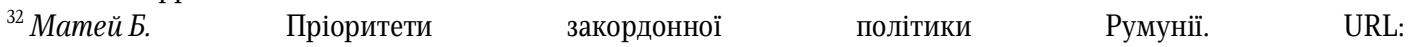
http://www.rri.ro/uk_uk/Пріоритети_закордонної_політики_Румунії-2526024
} 
К. Йоханіса Румунія підтримувала та підтримує проект обєднаної Європи з сильними інститутами та кращою координацією політики у всіх сферах.

Тепер слід звернути увагу на еволюцію російсько-румунських відносин і ставлення керівників держави Т. Бесеску і К. Йоханніса до перспектив співпраці з РФ.

3 приходом до влади Т. Бесеску у 2004 р. розпочалося жорстке протистояння політиці РФ з метою привернення уваги США до можливостей військово-політичного співробітництва з Румунією. У зовнішньополітичній діяльності Румунії пріоритетним стає саме проамериканський напрям ${ }^{33}$. А відносини з Москвою набувають все більшої напруженості та непорозумінь.

Розкриваючи російський напрямок зовнішньої політики Румунії за президентства Т. Бесеску зазначимо, що:

1) Каменем спотикання у двосторонніх відносинах між Румунією та Російською Федерацією стає Молдова. Спроба російського уряду розділити Молдову та створити Придністровську Республіку стала вузлом протиріч і відобразилася на відносинах РФ і Румунії у період з 2004 по 2014 рр.

2) Дуже гостро між цими державами постало питання і про розміщення на території Румунії елементів американської системи ПРО. Рішення Румунії укласти таку угоду 3 США викликало різку критику з боку РФ, оскільки сегменти ПРО можуть бути використані проти обмеження можливостей стратегічних ядерних сил Росії ${ }^{34}$

3) Російські інвестиції в Румунії за президентства Т. Бесеску залишалися практично єдиною сферою російсько-румунських відносин, що не зазнала значного впливу політичних протиріч.

4) Вперше за роки президентства Т. Бесеску, Румунія і Росія висловили схожість думок щодо конфлікту в Косово у 2008 р. й обидві держави не визнали цю новоутворену республіку, хоча і з різних причин. Але, це ніяк не вплинуло на розвиток конструктивного діалогу між Росією та Румунією.

5) Потрібно відзначити, що зовнішньополітичні ініціативи Т. Бесеску майже повністю відійшли від багаторічних традицій румунської дипломатії, що дуже суттєво позначилося на проведенні діалогу з РФ.

3 приходом до управління країною нового керівництва під егідою К. Йоханніса, російський напрям все ж набув більш економічних обрисів. Необхідно виділити найважливіші події, які відображають зміст російсько-румунських відносин упродовж 2014-2018 рр.:

1) У період з 2010 р. по 2014 р. тривав процес поліпшення ситуації у двосторонній торгівлі, що серйозно постраждала від глобальної економічної кризи, при цьому зберігалася сировинна спрямованість російського експорту до Румунії ${ }^{35}$

2) Враховуючи дії Росії щодо України (анексія Криму, початок війни та підтримка сепаратистських утворень), які призвели до дестабілізації регіону, Румунія офіційно підтримала Україну, засудивши поведінку та дії Російської Федерації. У результаті чого двосторонні румунсько-російські економічні відносини стають мінімальними.

\footnotetext{
${ }^{33}$ Кириллов В.Б. Отношения России и Румынии после 1989 года в контексте внешнеполитических приоритетов страны. С. 18.

${ }^{34}$ Ibid. C. 13-23.

${ }^{35}$ Российско-румынские торгово-экономические отношения. URL: http://romania.mid.ru/70
} 
3) Економічні відносини Румунії та РФ протягом 2014-2017 рр. характеризуються спадом і погіршенням. Через це Румунія переорієнтовується на нарощування економічних зв'язків з Китаєм і Туреччиною.

4) Починаючи 32018 р. Румунія намагається реалізувати стратегію мінімізації впливу РФ у регіоні, шляхом зменшення імпорту російського газу та заміщення його іншими джерелами енергії. Зазначимо, що К. Йоханніс виступав за спільну позицію Євросоюзу в питанні санкцій щодо РФ через ситуацію в Україні та пообіцяв, у разі необхідності, підтримати їх посилення. Позиція Румунії полягала у тому, щоб сприяти продовженню режиму санкцій ЄС щодо РФ поки не відбудеться повного застосування Мінських домовленостей.

5) К. Йоханніс виступає проти зайвого зближення Угорщини та Росії на тлі наростання напруженості у відносинах між ЄС і РФ через конфлікт в Україні.

Аналізуючи євроатлантичний вектор зовнішньої політики Румунії, варто зазначити, що Т. Бесеску доклав максимальних зусиль аби Румунія стала членом НАТО (29 березня 2004 р.). Оскільки, на його думку, це посилювало безпеку країни та створювало передумови для її приєднання до ЄС, а з іншого - зміцнювало південний фланг НАТО у Чорноморському регіоні. Приєднання Румунії до Північноатлантичного союзу було чітко сплановано та добре організоване керівництвом країни. Вступ до НАТО поставив військове співробітництво Румунії із США на новий, «винятковий» рівень. Завдяки співробітництву з НАТО Румунія перетворилася на одного з головних американських союзників у Европі.

У 2013 р. керівництвом США було прийняте вже остаточне рішення про розміщення системи ЄвроПРО на території свого союзника - Румунії. Участь румунської армії в різних операціях з підтримання миру й, особливо, присутність в Афганістані батальйону піхоти у Кандагарі, загону військової поліції у Кабулі та групи офіцерів у Баграмі зміцнило переконання союзників НАТО у здатності Румунії успішно виконувати покладені на неї завдання. Важливо додати і про обмін досвідом між альянсом і Румунією у військовій сфері. Румунських офіцерів масово відправляли в американські та натовські військові академії, а в Румунію прибували американські радники.

Румунська держава стала активним учасником військових і військово-медичних навчань під егідою НАТО, особливо після російсько-українського конфлікту щодо Кримського півострову та зосередження російських військ біля кордонів України. У травні 2014 р. стартували такі навчання за участі канадських та американських льотчиків.

За часів перебування при владі Т. Бесеску партнерство Румунії та НАТО було дуже динамічним і вельми необхідним для повноцінного розвитку обох сторін. Для збереження такої тісної співпраці необхідним стало обопільне надання кваліфікованої консультативної допомоги та створення належних умов для зменшення ризику загроз миру і безпеки у всьому світі.

Продовжувачем активізації євроатлантичного вектору зовнішньої політики Румунії стає й К. Йоханніс. Однак його розвиток будується на основі реалізації трьох структур: НАТО, ЄС і стратегічне партнерство із США.

У результаті США упродовж 2014-2018 рр. стають для Румунії гарантом її безпеки, солідним союзником і надійним партнером, з яким останню пов'язує міцна дружба, спі- 
льні цінності, принципи та загальні інтереси, і сильна прихильність до єдності та монолітності євроатлантичної сімї̈.

Румунія знаходиться у сприятливій економічній ситуації і робить важливі кроки у розкритті потенціалу двостороннього істотного торгово-економічного співробітництва із США.

Що стосується НАТО, то ця структура оцінюється за президентською програмою і рівнем політичного дискурсу як гарант національної безпеки, й один з основних напрямів зовнішньої політики та безпеки румунської держави.

3 точки зору К. Йоханніса Румунія є країною, розташованою на кордоні між Сходом і Заходом у складній області, яка характеризується періодичною нестійкістю, але яка шляхом співпраці з НАТО може стати важливою складовою на геополітичній карті регіону, що гарантує безпеку в сусідніх областях. Для цього, на думку К. Йоханніса, необхідний баланс між південним і східним флангами Північноатлантичного блоку в Європі.

К. Йоханніс вважав важливим зосередити увагу на силах як з Балтії та Польщі, так і з Румунії та Болгарії, зважаючи на кризу в Україні, яка спричинила значні зміни у геополітиці регіону. Збільшення оборонного бюджету мало стати можливістю технологічного співробітництва між румунською оборонною промисловістю та європейськими й американськими компаніями.

Отже, розглянувши ключові напрями зовнішньополітичної діяльності Румунії за президентства Т. Бесеску і К. Йоханніса, можемо сказати, що в основному вони були подібними, хоча й мали свої особливості. Так, після приходу до влади Т. Бесеску у 2004 р., президент заявив, що Румунія слідує трьом напрямкам у зовнішній політиці: приналежність до ЄС, до НАТО і стратегічне партнерство із США. Загалом, президентові вдалося виконати цю програму. Після вступу до ЄС, основним національним пріоритетом став вступ до Шенгенської зони. Також Румунія почала дуже активно просувати свої національні інтереси та регіональне лідерство у Південно-Східній Європі. Держава прагнула зайняти позицію «адвоката» для третіх країн щодо їх вступу до провідних міжнародних організацій. Однак, з обранням на посаду глави державного шляху» - прагнення Румунії відновити їі історичні території, які вона втратила після Другої світової війни, що викликало різку критику з боку країн Европейського Союзу.

В основі двосторонніх відносин з Росією лежали прагматичність і захист своїх зовнішніх ініціатив. Їх відносини, протягом президентства Т. Бесеску, стали особливо напруженими, бо він позиціонував себе як прозахідний та «антиросійський» політик. Президент намагався вжити деяких заходів для їх покращення, проте створення атмосфери довіри, відкритості, плідного й ефективного партнерства у вирішенні регіональних і міжнародних проблем Траянові Бесеску не вдалося досягти.

У свою чергу, К. Йоханніс, продовжуючи реалізацію трьох основних векторів зовнішньої політики і безпеки Румунії (співпраця з НАТО, ЕС і США), також робить акцент на співпраці з Молдовою та румунською громадою за кордоном. Беззаперечним принципом зовнішньополітичної діяльності Румунії залишається пріоритет членства в НАТО та ЄC; відносини із США, що мають стратегічний характер, і надалі поглиблюватимуться та розширюватимуться. Невід'ємним залишається й питання розширеної зони Чорного моря, яка межує з Європою, Центральною Азією та Середнім Сходом, та є зоною транзиту вуглеводнів. 


\title{
Liudmyla Vovchuk
}

\section{Romania's Foreign Policy Under Presidents T. Besescu and C. Johannis: comparative analysis}

\begin{abstract}
This article analyzes the foreign policy of Romania under Presidents T. Basescu and C. Johannes, both of whom made every effort to bring the country to a new level of development and establish it among the leading actors in the international arena as a stable country ready for cooperation both regionally and global levels. Thus, after T. Basescu came to power in 2004, the President stated that Romania follows three directions in foreign policy: membership in the EU, NATO and strategic partnership with the United States. In general, the president managed to implement this program. After joining the EU, the main national priority was joining the Schengen area. Romania has also begun to actively promote its national interests and regional leadership in Southeast Europe. In turn, according to K. Johannes, Romania's foreign policy and security also focus on these three main areas. But he also focuses on working with Moldova and the Romanian community abroad. The priority of Romania's foreign policy remains the priority of NATO and EU membership; relations with the United States, which are strategic in nature. Relations with the Russian Federation remain tense. Considering the key vectors of Romania's foreign policy during the presidencies of these two completely different figures, we can say that they were mostly similar, although they had their own characteristics.
\end{abstract}

Keywords: foreign policy, Romania, T. Basescu, C. Johannes, EU, USA, Russia 